\title{
PENGARUH KARAKTERISTIK DEWAN KOMISARIS TERHADAP KINERJA KEUANGAN PERUSAHAAN. STUDI KASUS PADA BUMN PERSERO TERBUKA TAHUN 2014-2018
}

\author{
THE IMPACT OF BOARD OF COMISSIONER CHARACTERISTICS ON THE FIRM FINANCIAL \\ PERFORMANCE. CASE STUDY AT PUBLIC LISTED SOES 2014-2018
}

\author{
Awal Susmanto*)1, Arief Daryanto ${ }^{* * *}$, dan Hendro Sasongko***) \\ *) Sekolah Bisnis, IPB University \\ Jl. Raya Pajajaran Bogor 16151, Indonesia \\ **) Departemen Ilmu Ekonomi, Fakultas Ekonomi dan Manjemen, IPB University \\ Jl. Agatis. Kampus IPB Darmaga, Bogor 16680, Indonesia \\ $\left.{ }^{* * *}\right)$ Fakultas Ekonomi, Universitas Pakuan \\ Jl. Pakuan PO Box 452 Bogor 16143, Indonesia
}

\begin{abstract}
In the corporate governance mechanism, the board of commissioners with its characteristics has a strategic role to increase the value of the company through the process of monitoring the management of the company by the board of directors. This study aims to analyze the effect of the characteristics of the board of commissioners on company performance (ROE and Tobin's Q) in public listed SOEs on the IDX for the 2014-2018 period. By using panel data regression analysis, the results show that the number of independent commissioners and the age of the board of commissioners has a significant positive effect on firm performance (ROE and Tobin's $Q$ ), while the educational level of board members and board meetings has a positive effect on ROE but has a negative effect on Tobin's $Q$. Meanwhile, the number of commissioners does not have a significant effect on ROE, but has a positive effect on Tobin's $Q$. The findings of this study can be used as a consideration for shareholders, in this case the Ministry of SOEs for the improvement of corporate governance mechanisms, especially in the aspect of the board of commissioners.
\end{abstract}

Keywords: board of commissioner, SOEs, corporate governance, firm financial performance, Ministry of SOEs

\begin{abstract}
Abstrak: Dalam mekanisme corporate governance, dewan komisaris dengan karakteristiknya mempunyai peran yang strategis untuk meningkatkan nilai perusahaan melalui proses pengawasan terhadap jalannya pengurusan perusahaan oleh direksi. Penelitian ini bertujuan menganalisis pengaruh karakteristik dewan komisaris terhadap kinerja perusahaan (ROE dan Tobin's Q) pada BUMN persero terbuka yang terdaftar di Bursa Efek Indonesia periode 2014-2018. Dengan menggunakan analisis regresi data panel, diperoleh hasil bahwa jumlah komisaris independen dan usia anggota dewan komisaris berpengaruh signifikan positif terhadap kinerja perusahaan (ROE dan Tobin's Q), sedangkan untuk tingkat pendidikan anggota dewan komisaris dan rapat dewan komisaris berpengaruh positif terhadap ROE, tetapi berpengaruh negatif terhadap Tobin's Q. Jumlah anggota dewan komisaris tidak berpengaruh signifikan terhadap ROE, tetapi berpengaruh positif terhadap Tobin's Q. Temuan penelitian dapat dijadikan sebagai salah satu bahan pertimbangan kepada pemegang saham dalam hal ini Kementerian BUMN bagi perbaikan pengaturan mekanisme corporate governance khususnya pada aspek dewan komisaris.
\end{abstract}

Kata kunci: corporate governance, BUMN, dewan komisaris, Kementerian BUMN, kinerja keuangan perusahaan

\footnotetext{
${ }^{1}$ Corresponding author:

Email: awalsusmanto@gmail.com
} 


\section{PENDAHULUAN}

BUMN persero terbuka yang terdaftar di Bursa Efek Indonesia (BEI) mempunyai posisi yang strategis dalam pembentukan IHSG yang menjadi salah satu indikator dalam perekonomian nasional. Kapitalisasi saham seluruh BUMN persero terbuka sampai dengan akhir tahun 2018 hampir mencapai 30\% dari total kapitalisasi emiten di BEI. Selain itu peran BUMN persero terbuka kepada negara juga sangat vital. Dari sisi kontribusi kepada pendapatan negara, di samping menjadi penyetor deviden, BUMN persero terbuka juga menyumbang penerimaan pajak bagi negara. Tidak hanya itu, BUMN persero terbuka dipandang sebagai penggerak perekonomian dan pembangunan bangsa melalui berbagai sektor usahanya, mulai dari sektor keuangan dan perbankan, sektor telekomunikasi sampai sektor infratruktur.

Dengan posisinya yang sangat strategis, BUMN persero terbuka tersebut harus dikelola dengan profesional dengan cara menerapkan praktik-praktik good corporate governance dalam menjalankan bisnisnya sebagaimana yang diatur di dalam Undang-Undang Nomor 19 Tahun 2003 tentang Badan Usaha Milik Negara dan diatur lebih rinci pada Peraturan Menteri BUMN Nomor: PER-01/MBU/2011 tentang Penerapan tata Kelola Yang Baik (Good Corporate Governance) Pada Badan Usaha Milik Negara. Tujuannya adalah untuk menjaga dan meningkatkan kinerja perusahaan yang tercermin dalam kinerja keuangannya dan juga kinerja nilai saham di pasar.

Dalam mekanisme corporate governance di Indonesia yang menganut sistem two-tier, pemegang saham mendelegasikan kewenangan untuk melakukan pengawasanataspengurusanperusahaanyangdijalankan oleh direksi kepada dewan komisaris. Dengan demikian dewan komisaris dengan karakteristik yang dimilikinya mempunyai peran yang strategis untuk meningkatkan nilai perusahaan melalui proses pengawasan terhadap jalannya pengurusan perusahaan oleh direksi.

Karakteristik dewan komisaris seperti jumlah anggota dewan komisaris, rapat dewan komisaris, jumlah komisaris independen telah dijelaskan di dalam berbagai aturan dan regulasi di antaranya adalah UndangUndang Nomor 19 Tahun 2003 tentang Badan Usaha Milik Negara dan Undang-Undang Nomor 40 Tahun 2007 tentang Perseroan Terbatas. Selanjutnya, terdapat karakteristik belum diatur secara eksplisit dalam aturan seperti karakteristik usia anggota dewan komisaris dan tingkat pendidikan anggota dewan komisaris. Namun demikian, dalam berbagai penelitian ilmiah seperti Nakano dan Nguyen (2011) dan Dagsson dan Larsson (2011) karakteristik tersebut dianggap sejalan dengan teori keagenan. Teori keagenan (agency theory) sendiri mengidentifikasi hubungan keagenan, di mana satu pihak (prinsipal) mendelegasikan pekerjaan ke pihak lain (agen). Dalam konteks korporasi, prinsipal adalah pemegang saham dan direksi adalah agen. Hal ini sebagaimana dijelaskan oleh Jensen dan Meckling (1976).

Penelitian-penelitian terkait pengaruh karakteristik dewan komisaris terhadap kinerja perusahaan selalu dikaitkan dengan mekanisme corporate governance. Ukuran kinerja perusahaan yang diteliti sebagian besar menggunakan rasio keuangan berbasis akuntansi seperti rasio profitabilitas (Vivekananda et al. 2019) dan nilai pasar perusahaan. Sejauh pengetahuan peneliti, dalam konteks Indonesia, objek penelitian terkait dengan topik ini adalah meneliti perusahaan-perusahaan yang terdaftar di BEI, Namun demikian, belum terdapat penelitian yang spesifik meneliti BUMN persero terbuka secara spesifik.

Dalam penelitian ini, pendekatan yang digunakan adalah dengan cara melakukan analisis pengaruh variabelvariabel penelitian (karakteristik dewan komisaris) terhadap kinerja keuangan perusahaan, dalam hal ini ROE dan Tobin's Q. Ukuran jumlah anggota dewan komisaris dalam melakukan kegiatan monitoring dan penasihatan kepada dewan direksi dalam mengelola perusahaan menjadi salah satu karakteristik yang menjadi bahasan dalam konteks corporate governance. Jumlah anggota dewan komisaris dianggap sebagai salah satu faktor yang berpengaruh positif dalam meningkatkan kinerja perusahaan. Alasannya adalah dengan semakin banyaknya jumlah komisaris yang memadai, maka agenda monitoring, supervisi dan penasihatan menjadi semakin baik (Coles et al. 2018, Meyer dan de Wet, 2013, Darweesh, 2015). Namun demikan, dengan semakin banyaknya jumlah anggota dewan komisaris akan muncul hambatan dalam berkomunikasi, terdapat salah satu anggota dewan komisaris yang menjadi free-rider. Selain itu, dengan semakin banyak jumlah anggota dewan komisaris maka posisi keberadaan dewan komisaris pada akhirnya hanya dianggap sebagai simbol. Oleh karena itu, dalam beberapa studi menyebutkan bahwa jumlah dewan komisaris yang lebih kecil dianggap mampu 
untuk mengatasi hambatan komunikasi dan adanya free rider serta akan cenderung lebih efektif dalam bekerja (Afshan et al. 2016).

Kemudian, dengan semakin banyaknya jumlah anggota dewan komisaris maka posisi keberadaan dewan komisaris pada akhirnya hanya dianggap sebagai simbol. Oleh karena itu dalam beberapa studi menyebutkan bahwa jumlah dewan komisaris yang lebih kecil dianggap mampu untuk mengatasi hambatan komunikasi dan adanya free rider serta akan cenderung lebih efektif dalam bekerja (Bhat et al. 2018).

Karakteristik berikutnya adalah rapat dewan komisaris. Rapat dewan komisaris merupakan sarana yang digunakan untuk melakukan supervisi, monitoring, memberikan nasihat kepada dewan direksi. Selain itu rapat dewan komisaris digunakan oleh dewan komisaris untuk mengumpulkan informasi terkait berbagai isu strategis perusahaan sebagai bahan untuk memberikan keputusan (Chou et al. 2013). Dengan adanya rapat yang dilaksanakan secara rutin maka kinerja perusahaan akan dapat terus dipantau sehingga kinerja perusahaan diharapkan juga meningkat (Al-Daoud et al. 2016, Hidayat dan Utama, 2016, Ntim dan Osei, 2011).

Menurut Rashid (2018), sejalan dengan teori keagenan yang menjelaskan bahwa fungsi monitoring dewan komisaris terhadap jalannya perusahaan akan lebih efektif jika terdapat anggota dewan komisaris yang berasal dari luar pemilik perusahaan (komisaris independen). Hal ini disebabkan karena dengan tidak adanya pemisahan yang jelas antara kepemilikan dan manajemen, dapat menyebabkan perusahaan cenderung berjalan sesuai dengan kepentingan pemegang saham pengendali, dan bukan untuk kepentingan perusahaan (Hidayat dan Utama 2016). Salah satu karakteristik dewan komisaris yang mempengaruhi kinerja perusahaan adalah keberadaan anggota komisaris independen di dalam komposisi dewan komisaris (Bohorquez et al. 2018, Liu et al. 2014).

Kualifikasi yang dimiliki oleh para anggota dewan komisaris sangat penting di dalam melaksanakan tugas monitoring perusahaan. Salah satu kualifikasi yang menjadi pertimbangan dalam pengangkatan anggota dewan komisaris adalah tingkat pendidikan. Setiap perusahaan dengan perbedaan bidang industri tentu saja membutuhkan dewan komisaris yang profesional. Selain itu, investor akan lebih percaya dengan perusahaan yang mempunyai dewan komisaris dengan tingkat pendidikan yang lebih tinggi (Girbina et al. 2012).

Selain dari beberapa karakteristik yang telah disebutkan di atas, faktor usia anggota dewan komisaris juga dianggap menjadi salah satu faktor yang mempengaruhi kinerja perusahaan. Komposisi rata-rata usia yang lebih tua dalam susunan dewan komisaris dapat dianggap bahwa dewan komisaris tersebut mempunyai lebih banyak pengalaman (Nakano dan Nguyen 2011). Adapun komposisi rata-rata usia yang lebih muda dalam susunan dewan komisaris dapat dianggap bahwa dewan komisaris tersebut mempunyai kemampuan untuk memutuskan beberapa permasalahan strategis perusahaan yang berisiko dan lebih mempunyai motivasi dalam bekerja (Dagsson dan Larsson 2011).

Berdasarkan latar belakang tersebut, penelitian ini bertujuan (1) melakukan analisis pengaruh jumlah anggota dewan komisaris terhadap kinerja perusahaan; (2) melakukan analisis pengaruh rapat dewan komisaris terhadap kinerja perusahaan; (3) melakukan analisis pengaruh jumlah komisaris independen terhadap kinerja perusahaan; (4) melakukan analisis pengaruh tingkat pendidikan anggota dewan komisaris terhadap kinerja perusahaan; dan (5) melakukan analisis pengaruh usia anggota dewan komisaris terhadap kinerja perusahaan. Kinerja perusahaan yang diukur adalah ROE dan Tobin's Q pada BUMN persero terbuka pada periode 2014-2018.

\section{METODE PENELITIAN}

Penelitian dilakukan di Kantor Kementerian BUMN, J1. Medan Merdeka Selatan Nomor 13 Jakarta Pusat selama 2 bulan (Agustus-September 2020). Data yang digunakan dalam penelitianmenggunakan datasekunder yaitu melalui pengumpulan referensi dari berbagai literatur terkait penelitian. Data variabel penelitian diambil dan diolah dari Laporan Keuangan Tahunan dan Laporan Tahunan (Annual Report) BUMN persero terbuka periode 2014-2018. Objek penelitian ini adalah 20 BUMN persero terbuka yang terdaftar di Bursa Efek Indonesia periode 2014-2018.

Pengambilan data pada penelitian ini menggunakan metode purposive sampling. Populasi dalam penelitian ini adalah seluruh perusahaan terbuka/emiten yang terdaftar di BEI sampai dengan akhir tahun 2018, yaitu sebanyak 600 perusahaan. Adapun sampel penelitian 
ini adalah BUMN persero terbuka yang terdaftar di BEI. Terdapat 20 BUMN persero terbuka yang sudah terdaftar di Bursa Efek Indonesia (BEI) selama periode tahun 2014-2018 (5 tahun).

Penelitian ini menggunakan pendekatan deskriptif yaitu memberikan gambaran terkait dengan variabel yang akan diteliti. Adapun metode yang digunakan dalam penelitian ini adalah menggunakan metode analisis hubungan kausal (penelitian ini dirancang untuk menguji pengaruh karakteristik dewan komisaris terhadap kinerja perusahaan).

Dari laporan tahunan tersebut, diperoleh data yang akan menjadi variabel penelitian diantaranya adalah data jumlah anggota dewan komisaris, rapat dewan komisaris, jumlah komisaris independen, tingkat pendidikan anggota dewan komisaris, usia anggota dewan komisaris pada setiap BUMN persero terbuka yang menjadi objek penelitian. Selain itu juga diperoleh data variabel kontrol, yaitu ukuran perusahan dan usia perusahaan. Dalam beberapa penelitian disebutkan bahwa semakin lama usia perusahaan beroperasi maka akan berpengaruh secara negatif terhadap kinerja perusahaan, sebaliknya perusahaan yang berusia lebih muda akan cenderung lebih agresif dalam peningkatan kinerja (Selcuk, 2016). Menurut penelitian Ahmed dan Hamdan (2015), usia perusahaan justru berpengaruh signifikan terhadap kinerja perusahaan. Temuan Marashdeh (2014) juga menunjukkan bahwa ukuran perusahaan mempunyai pengaruh yang signifikan terhadap kinerja perusahaan (ROE). Adapun penelitian Astuti et al. (2018) menyatakan bahwa ukuran perusahaan tidak bepengaruh signifikan terhadap nilai perusahaan (Tobin's Q).

Dan variabel dependen yaitu Return on Equity dan data Tobin's $Q$. Kemudian data tersebut diolah dengan menggunakan regresi data panel dengan memilih estimasi model regresi terbaik terbaik antara common effect model, fixed effect model atau random effect model melalui uji estimasi yaitu uji Chow, uji Hausman dan atau/ uji Lagrange Multiplier kemudian dilakukan uji asumsi klasik untuk diperoleh model persamaan regresi data panel terbaik. Adapun persamaan regresi panel untuk penelitian ini adalah sebagai berikut:

$$
\begin{aligned}
\mathrm{KP}(\mathrm{ROE} ; \mathrm{TOBIN} \text { ' S Q })= & \alpha+\beta \mathrm{JKOMit}+\beta \text { RKOMit } \\
& +\beta \text { KINDPit }+\beta \text { TPKOMit } \\
& +\beta \text { UKOMit }+\beta \text { UKPERit }+ \\
& \beta \text { USPERit }+ \text { cit }
\end{aligned}
$$

Keterangan: KP (Kinerja Perusahaan (ROE dan Tobin's Q)); $\alpha$ (intersep); $\beta$ (koefisien regresi/slope); JKOM (Variabel Jumlah Komisaris); RKOM (Variabel Rapat Komisaris); KINDP (Variabel Komisaris Independen); TPKOM (Variabel Tingkat Pendidikan Komisaris); UKOM (Variabel Usia Komisaris); UKPER (Variabel Ukuran Perusahaan); USPER (Variabel Usia Perusahaan); cit (nilai galat pada unit data tabel silang ke-i dan waktu ke-t)).

Penelitian ini berusaha untuk membuktikan beberapa hipotesis yang terangkum di dalam model kerangka pemikiran sebagaimana Gambar 1.

H1 : Jumlah anggota dewan komisaris berpengaruh negatif terhadap kinerja perusahaan. Semakin banyak jumlah komisaris maka pengawasan yang dilakukannya semakin tidak efektif. Dengan demikian nilai ROE dan Tobin's Q akan turun

H2 : Rapat dewan komisaris berpengaruh positif terhadap kinerja perusahaan. Dengan adanya rapat komisaris yang di dalamnya membahas berbagai aspek strategis terkait jalannya pengurusan perusahaan oleh direksi, maka diharapkan kinerja keuangan (ROE dan Tobin's Q) perusahaan meningkat

H3 : Jumlah anggota dewan komisaris independen berpengaruh positif terhadap kinerja perusahaan. Saran dan nasihat yang diberikan komisaris independen kepada direksi akan lebih kredibel dan pada akhirnya akan meningkatkan kinerja keuangan perusahaan (ROE dan Tobin'sQ akan meningkat).

H4 : Tingkat pendidikan anggota dewan komisaris berpengaruh positif terhadap kinerja perusahaan. Perusahaan dengan komposisi komisaris yang mempunyai tingkat pendidikan yang tinggi akan cenderung lebih dipercaya oleh pasar sehingga meningkatkan ROE dan Tobin's Q

H5 : Usia anggota dewan komisaris berpengaruh positif terhadap kinerja perusahaan. Semakin matang usia komisaris dengan ditandai banyaknya pengalaman di bidang tugasnya, maka dalam menjalankan tugas monitoring serta penasihatan kepada direksi akan semakin berhati-hati dan cermat sehingga dapat meningkatkan kinerja keuangan perusahaan (nilai ROE dan Tobin's Q meningkat). 
HASIL

\section{Analisis Statistik Deskriptif}

Tabel 1 menunjukkan hasil statistik deskriptif yang memberikan gambaran informasi karakteristik variabel penelitian ini, yaitu variabel kinerja perusahaan yang merupakan variabel dependen (ROE dan Tobins'Q), kemudian karakteristik dewan komisaris yang merupakan variabel independen yaitu variabel jumlah anggota dewan komisaris (JKOM), rapat dewan komisaris (RKOM), jumlah komisaris independen (KINDP), tingkat pendidikan anggota dewan komisaris
(TPKOM) dan usia anggota dewan komisaris (UKOM) serta variabel kontrol yaitu ukuran perusahaan (UKOM) dan usia perusahaan (USPER).

\section{Pengujian Persyaratan Analisis Data}

Berdasarkan pemilihan estimasi model regresi panel dengan menggunakan aplikasi Eviews 10 antara 2 model penelitian (ROE dan Tobin's Q) menggunakan uji Chow dan Hausman didapatkan model terbaik yang digunakan menjadi model persamaan regresi yaitu fixed effect model.

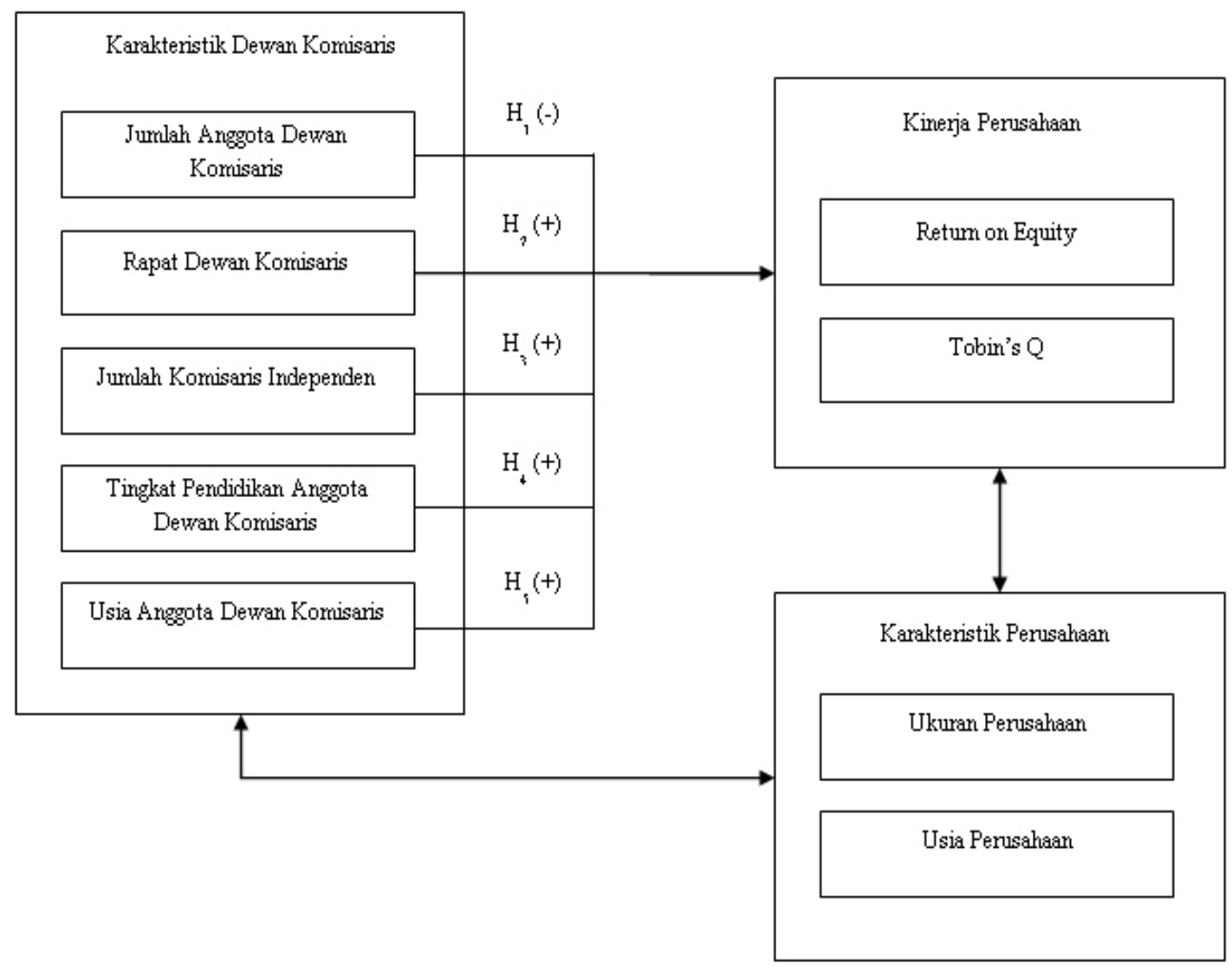

Gambar 1. Kerangka pemikiran penelitian

Tabel 1. Deskripsi statistik variabel penelitian

\begin{tabular}{lccccccccc}
\hline Ukuran & ROE & TOBINS_Q & JKOM & RKOM & KINDP & TPKOM & UKOM & UKPER & USPER \\
\hline Mean & 0,117 & 1,869 & 6,240 & 0,355 & 0,405 & 0,777 & 56,368 & 31,457 & 12,500 \\
Median & 0,130 & 1,199 & 6,000 & 0,288 & 0,333 & 0,833 & 56,607 & 31,392 & 12,500 \\
Maximum & 0,393 & 14,623 & 9,000 & 1,096 & 0,714 & 1,000 & 64,000 & 34,799 & 27,000 \\
Minimum & $-0,420$ & 0,608 & 3,000 & 0,077 & 0,200 & 0,200 & 47,500 & 27,853 & 1,000 \\
Std.Dev & 0,126 & 2,224 & 1,288 & 0,202 & 0,103 & 0,196 & 3,156 & 1,734 & 6,408 \\
Observations & 100 & 100 & 100 & 100 & 100 & 100 & 100 & 100 & 100 \\
\hline
\end{tabular}


Uji Chow (pemilihan model antara common effect atau fixed effect)

Untuk menentukan apakah model terbaik untuk data adalah fixed effect model atau common effect model dapat dilakukan dengan uji Chow dengan ketentuan sebagai berikut:

Hipotesis

$\mathrm{H}_{0}$ : Model mengikuti common effect

$\mathrm{H}_{1}$ : Model mengikuti fixed effect

Taraf signifikansi: $\alpha=5 \%$

Keputusan: tolak $\mathrm{H}_{0}$ jika $p$-value $<\alpha$

Berdasarkan hasil pengujian yang ditunjukan oleh Tabel 2, uji cross-section $\mathrm{F}$ adalah signifikan untuk kedua model (p-value $=0,000$ dan 0,0001 lebih kecil dari $0,05)$, sehingga dapat disimpulkan bahwa model fixed effect lebih tepat bagi kedua model (ROE dan Tobin's Q) dibandingkan dengan model common effect.

Uji Hausman (pemilihan model antara fixed effect atau random effect)

Untuk menentukan apakah model terbaik untuk data adalah fixed effect model atau random effect model dapat dilakukan dengan uji Hausman dengan ketentuan sebagai berikut:

Hipotesis

$\mathrm{H}_{0}$ : Model mengikuti random effect

$\mathrm{H}_{1}$ : Model mengikuti fixed effect

Taraf signifikansi: $\alpha=5 \%$

Keputusan: tolak $\mathrm{H}_{0}$ jika p-value $<\alpha$

Berdasarkan hasil pengujian yang ditunjukan oleh Tabel 3 menunjukkan uji-Hausman (cross-section random) untuk kedua model adalah signifikan (p-value $=0,0232$ dan 0,00063 lebih kecil dari 0,05), sehingga dapat disimpulkan bahwa bahwa model fixed effect lebih tepat bagi kedua model (ROE dan Tobin's Q) dibandingkan dengan model random effect.

Setelah itu dilakukan uji asumsi klasik (normalitas, multikolinearitas, heteroskedastisitas dan autokorelasi) untuk memenuhi asumsi BLUE (Best, Linear, Unbiased, dan Estimator). Hasil uji asumsi normalitas menggunakan Jarque-Bera untuk kedua model (Tobins'Q dan ROE) dengan hipotesis $\mathrm{H}_{0}$ : residual menyebar normal; $\mathrm{H}_{1}$ : residual tidak menyebar normal. Simpulan hasil Jarque Bera untuk kedua model sebagaimana ditunjukkan pada Gambar 2 dan Gambar 3 adalah menunjukkan bahwa residual menyebar secara normal, hal ini karena pada nilai probabilitas JarqueBera untuk model Tobins'Q dan ROE menunjukkan nilai sebesar $(0.149)$ dan $(0,117)$ lebih besar dari alpha (0.05) maka keputusannya terima Ho.

\section{Uji Hipotesis}

\section{Uji F (uji simultan)}

Berdasarkan Tabel 4 diketahui bahwa nilai probabilitas $F$-statistic untuk model ROE dan model Tobin's Q adalah 0,0000 dan 0,0000 . Nilai tersebut $<0,05$, sehingga H1 diterima dan $\mathrm{H}_{0}$ ditolak. Hal tersebut menunjukkan bahwa jumlah anggota dewan komisaris, rapat dewan komisaris, jumlah komisaris independen, tingkat pendidikan anggota komisaris, usia anggota dewan komisaris, ukuran perusahaan dan usia perusahaan secara bersama-sama (simultan) berpengaruh terhadap kinerja perusahaan (ROE dan Tobin's Q).

Tabel 2. Hasil uji Chow model regresi ROE dan Tobin's Q

\begin{tabular}{lcccc}
\hline & \multicolumn{2}{c}{ Model ROE } & \multicolumn{2}{c}{ Model Tobin's Q } \\
\hline Effects Test & Statistic & Prob. & Statistic & Prob. \\
Cross-section F & 7,670103 & 0,0000 & 3,493367 & 0,0001 \\
Cross-section Chi-square & 109,73875 & 0,0000 & 64,67013 & 0,0000 \\
\hline
\end{tabular}

Tabel 3. Hasil uji Hausman model regresi ROE dan Tobin's Q

\begin{tabular}{lcccc}
\hline & Model ROE & \multicolumn{2}{c}{ Model Tobin's Q } \\
\hline Test Summary & Chi-Sq. Statistic & Prob. & Chi-Sq. Statistic & Prob. \\
Cross-section random & 16,222478 & 0,0232 & 19,68693 & 0,0063 \\
\hline
\end{tabular}




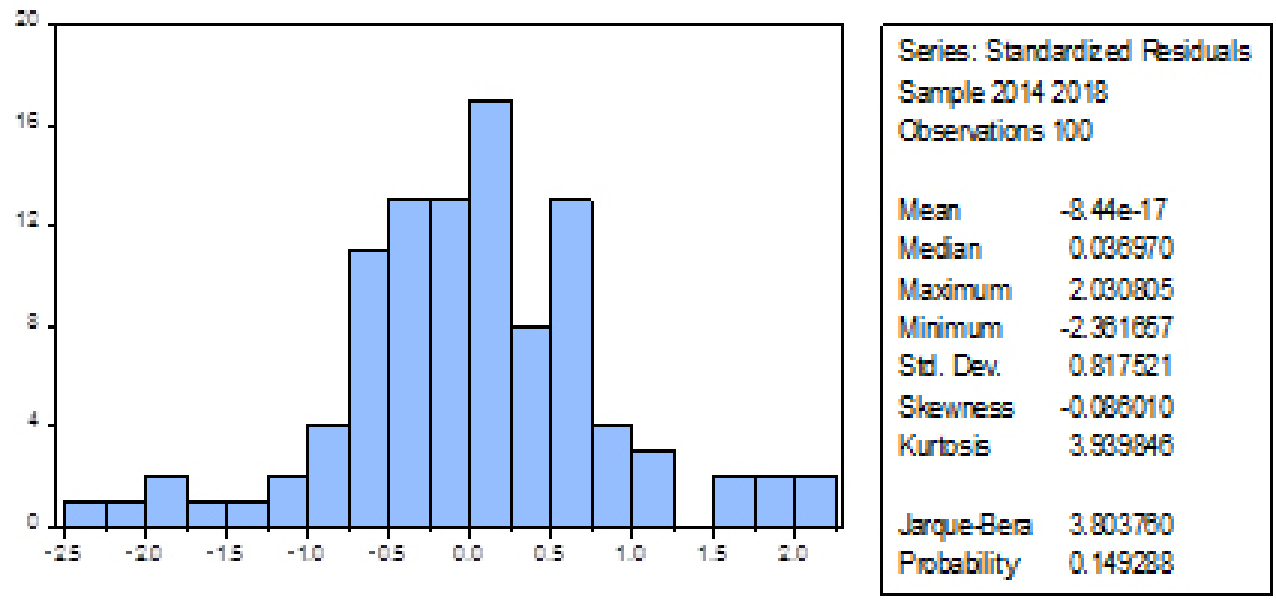

Gambar 2. Hasil uji normalitas Jarque-Bera model Tobins'Q

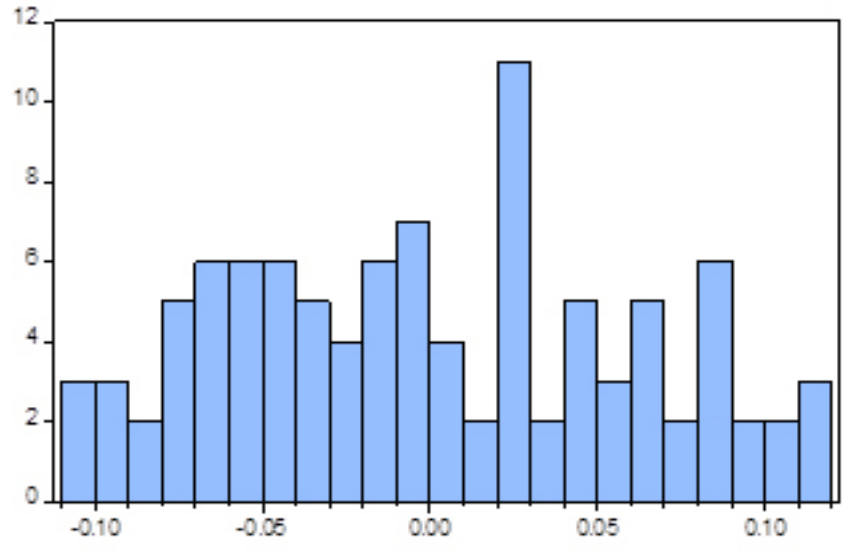

$\begin{array}{lc}\text { Series: Standardized Res iduals } \\ \text { Sample 2014 } 2018 \\ \text { Obs enations } & 100 \\ & \\ \text { Mean } & -1.39 e-18 \\ \text { Median } & -0.003634 \\ \text { Maximum } & 0.118867 \\ \text { Minimum } & -0.108943 \\ \text { Std. Dev. } & 0.059148 \\ \text { Skewness } & 0.149399 \\ \text { Kurtosis } & 2.030956 \\ & \\ \text { Jarque-Bera } & 4.284692 \\ \text { Probability } & 0.117379\end{array}$

Gambar 3. Hasil uji normalitas Jarque-Bera model ROE

Tabel 4. Ringkasan hasil model regresi penelitian

\begin{tabular}{lcccccc}
\hline \multirow{2}{*}{ Variabel } & \multicolumn{3}{c}{ Model ROE } & \multicolumn{3}{c}{ Model Tobin's Q } \\
\cline { 2 - 7 } & Coeff & $t$-Stat & Prob. & Coeff & $t$-Stat & Prob. \\
\hline C & $-1,372718$ & $-5,149823$ & 0,0000 & 21,46398 & & 0,0000 \\
JKOM & 0,008380 & 1,772619 & 0,0805 & 0,065475 & 2,947070 & 0,0043 \\
RKOM & 0,067361 & 5,278173 & 0,0000 & $-0,161661$ & $-0,945151$ & 0,3477 \\
KINDP & 0,129937 & 2,559237 & 0,0126 & 0,513845 & 2,423080 & 0,0178 \\
TPKOM & 0,068453 & 2,221375 & 0,0294 & $-0,362170$ & $-2,979256$ & 0,0039 \\
UKOM & 0,002956 & 5,206654 & 0,0000 & 0,039153 & 5,054031 & 0,0000 \\
UKPER & 0,044676 & 6,173088 & 0,0000 & $-0,701916$ & $-9,470149$ & 0,0000 \\
USPER & $-0,021137$ & $-10,50998$ & 0,0000 & & & \\
\hline R-squared & 0,896728 & & & 0,820865 & & \\
Adjusted $R$-squared & 0,859946 & & & 0,760347 & & \\
F-statistic & 24,37954 & & & 13,56389 & & \\
Prob (F-statistic) & 0,000000 & & & & & \\
\hline
\end{tabular}




\section{Uji t (uji parsial)}

\section{Model ROE}

Berdasarkan Tabel 4, diketahui bahwa nilai p-value variabel RKOM, KINDP, TPKOM, UKOM, UKPER DAN USPER $<0,05$ yang menunjukkan bahwa masingmasing variabel tersebut secara statistik memiliki pengaruh yang signifikan terhadap ROE pada taraf signifikansi 5\%. Sedangkan untuk variabel JKOM memiliki nilai p-value $<0,05$ yang dapat diartikan bahwa variabel tersebut tidak memiliki pengaruh yang signifikan terhadap ROE pada taraf signifikansi 5\%.

\section{Model Tobin's Q}

Berdasarkan Tabel 4, diketahui bahwa nilai p-value variabel JKOM, KINDP, TPKOM, UKOM dan UKPER $<0,05$ yang menunjukkan bahwa masing-masing variabel tersebut secara statistik memiliki pengaruh yang signifikan terhadap Tobin's Q pada taraf signifikansi 5\%. Sedangkan untuk variabel RKOM memiliki nilai $p$-value $>0,05$ yang dapat diartikan bahwa variabel tersebut tidak memiliki pengaruh yang signifikan terhadap Tobin's Q pada taraf signifikansi $5 \%$.

\section{Adjusted R-squared}

\section{Model ROE}

Berdasarkan Tabel 4, diketahui bahwa nilai adjusted $\mathrm{R}^{2}$ pada model ROE adalah sebesar 0,859946 yang menunjukkan bahwa $85,99 \%$ persen keragaman dari ROE dapat dijelaskan oleh variabel-variabel independen sedangkan sisanya yaitu sebesar 14,01\% dijelaskan oleh variabel lain di luar model penelitian.

\section{Model Tobin's Q}

Berdasarkan Tabel 4, diketahui bahwa nilai adjusted $\mathrm{R}^{2}$ pada model Tobin's $\mathrm{Q}$ adalah sebesar 0,760347 yang menunjukkan bahwa $76,03 \%$ persen keragaman dari Tobin's Q dapat dijelaskan oleh variabel-variabel independen sedangkan sisanya, yaitu sebesar 23,97\% dijelaskan oleh variabel lain di luar model penelitian.

\section{Analisis Pengaruh Jumlah Anggota Dewan Komisaris terhadap Kinerja Perusahaan}

Hipotesis $1\left(\mathrm{H}_{1}\right)$ penelitian ini adalah bahwa jumlah anggota dewan komisaris berpengaruh negatif terhadap kinerja perusahaan. Berdasarkan Tabel 4 dapat disimpulkan bahwa hasil temuan penelitian ini tidak mendukung $\mathrm{H}_{1}$ untuk model ROE dan juga model Tobin's Q.

Untuk model ROE, nilai probabilitas t-statistic (p-value) variabel jumlah komisaris (JKOM) adalah 0.0805 lebih besar dari $>(\alpha=5 \%)$ dengan tanda koefisien positif $(0,008)$ yang berarti bahwa variabel JKOM tidak mempunyai pengaruh yang signifikan terhadap kinerja perusahaan (dalam hal ini ROE). Temuan ini sejalan dengan penelitian Kao et.al (2018) yang menyatakan bahwa jumlah anggota dewan komisaris tidak mempunyai pengaruh signifikan terhadap kinerja perusahaan (dalam hal ini ROE). Alasannya adalah bahwa peran dewan komisaris tidak secara langsung terlibat di dalam pengurusan harian perusahaan.

Sementara itu, pada model Tobin's Q, penelitian ini ternyata menunjukkan bahwa variabel jumlah anggota dewan komisaris berpengaruh signifikan positif terhadap kinerja perusahan (dalam hal ini Tobin's Q). Hal ini terlihat dari nilai probabilitas $t$-statistic ( $p$-value) variabel jumlah anggota dewan komisaris (JKOM) sebesar $0,043<(\alpha=5 \%)$ dengan tanda koefisien positif $(0,065)$. Temuan ini sejalan dengan beberapa penelitian sebelumnya di antaranya Meyer dan Wet (2013), Hidayat dan Utama (2016), Mohamed et al. (2016) yang menjelaskan bahwa jumlah anggota dewan komisaris mempunyai pengaruh signifikan positif terhadap Tobin's Q. Argumen dari temuan penelitian ini adalah dengan dengan semakin besar jumlah anggota dewan komisaris, maka akan semakin mempeluas jaringan, diversifikasi keahlian antar anggota dewan komisaris dan juga akan semakin banyak masukan/ide dari para anggota dewan komisaris kepada direksi dalam menentukan pengambilan keputusan. 


\section{Analisis Pengaruh Rapat Dewan Komisaris terhadap Kinerja Perusahaan}

Hipotesis $2\left(\mathrm{H}_{2}\right)$ penelitian ini adalah bahwa rapat dewan komisaris berpengaruh positif terhadap kinerja perusahaan. Berdasarkan Tabel 4 dapat disimpulkan bahwa hasil temuan penelitian ini mendukung $\mathrm{H}_{2}$ tuntuk model ROE akan tetapi tidak mendukung $\mathrm{H}_{2}$ untuk model Tobin's Q.

Untuk model ROE, nilai probabilitast-statistic (p-value) variabel rapat dewan komisaris (RKOM) adalah 0,0000 $<(\alpha=5 \%)$ dengan tanda koefisien positif 0,067 yang berarti bahwa variabel RKOM berpengaruh signifikan positif terhadap kinerja perusahaan (dalam hal ini ROE). Temuan penelitian ini sejalan dengan beberapa penelitian sebelumnya yang menunjukkan bahwa jumlah rapat dewan komisaris mempunyai pengaruh signifikan terhadap kinerja perusahaan, di antaranya adalah penelitian yang dilakukan oleh Buachoom (2018) terhadap perusahaan terbuka di Thailand. Selain itu penelitian yang dilakukan oleh Vafeas (1999) menemukan bahwa rapat dewan komisaris yang dilakukan pada saat kondisi perusahaan mengalami permasalahan seringkali akan meningkatkan kinerja keuangan.

Namun demikian, temuan penelitian ini justru tidak mendukung $\mathrm{H}_{2}$ pada model Tobin's Q, di mana variabel RKOM tidak mempunyai pengaruh yang signifikan terhadap kinerja perusahan (dalam hal ini Tobin's Q). Hal ini terlihat dari nilai probabilitas $t$-statistic ( $p$-value) variabel rapat dewan komisaris (RKOM) sebesar 0,3477 $>(\alpha=5 \%)$ dengan tanda koefisien $-0,161$. Meskipun untuk model Tobin's Q, jumlah rapat dewan komisaris tidak mempunyai pengaruh yang signifikan, akan tetapi yang menarik dalam temuan penelitian ini adalah terdapat perbedaan arah koefisien antara model ROE yang arah koefisiennya positif dengan model Tobin's $\mathrm{Q}$ yang mempunyai arah koefisien negatif. Terdapat beberapa alasan terhadap temuan tersebut, diantaranya adalah bahwa semakin banyak frekuensi rapat dewan komisaris yang dilakukan menandakan perusahaan tersebut dalam keadaan yang tidak baik. Pasar akan bereaksi negatif terhadap hal yang demikian. Sementara itu, dengan semakin banyaknya jumlah frekuensi rapat dewan komisaris maka akan meningkatkan biaya yang akan berdampak negatif terhadap nilai perusahaan (Vafeas, 1999).
Hal ini sejalan dengan beberapa penelitian terdahulu yang justru menemukan bahwa rapat dewan komisaris mempunyai pengaruh yang negatif terhadap kinerja perusahaan. Dalam konteks penelitian perusahaan di Spanyol, Rodriguez-Fernandez et al. (2014) menyebutkan bahwa banyaknya frekuensi jumlah rapat dewan komisaris tidak mempunyai pengaruh terhadap kinerja perusahaan.

\section{Analisis Pengaruh Jumlah Anggota Komisaris Independen terhadap Kinerja Perusahaan}

Hipotesis $3\left(\mathrm{H}_{3}\right)$ penelitian ini adalah bahwa jumlah anggota dewan komisaris independen berpengaruh positif terhadap kinerja perusahaan. Berdasarkan Tabel 4 dapat disimpulkan bahwa hasil temuan penelitian ini mendukung $\mathrm{H}_{3}$ untuk model ROE dan model Tobin's Q.

Untuk model ROE, nilai probabilitas t-statistic ( $p$-value) variabel jumlah komisaris independen (KINDP) adalah $0,0126<(\alpha=5 \%)$ dengan tanda koefisien positif $(0,129)$ yang berarti bahwa variabel KINDP berpengaruh signifikan positif terhadap kinerja perusahaan (dalam hal ini ROE). Demikian juga untuk model Tobin's Q, nilai probabilitas $t$-statistic ( $p$-value) variabel jumlah komisaris independen (KINDP) adalah $0,0178<(\alpha=$ $5 \%)$ dengan tanda koefisien positif $(0,513)$ yang berarti bahwa variabel KINDP berpengaruh signifikan positif terhadap kinerja perusahaan (dalam hal ini Tobin's Q).

Temuan penelitian ini sejalan dengan beberapa penelitian sebelumnya yang menunjukkan bahwa jumlah komisaris independen mempunyai pengaruh signifikan terhadap kinerja perusahaan di antaranya adalah penelitian Liu et al. (2014) terhadap perusahaan di China, Black dan Khanna (2007) di India, Black dan Kim (2012) di Korea, sedangkan dalam konteks perusahaan di Indonesia adalah penelitian Hidayat dan Utama (2016).

Penelitian Liu et al. (2014) misalnya, menemukan bahwa jumlah komisaris independen dalam susunan dewan komisaris di perusahaan-perusahaan terbuka di China yang sebagian besar sahamnya dimiliki negara memiliki pengaruh positif terhadap kinerja perusahaan. Menurutnya, dalam konteks temuan tersebut, keberadaan komisaris independen setidaknya dapat mengurangi ketidakefisienan terkait dengan kepemilikan saham mayoritas milik pemerintah dan juga mengurangi konflik keagenan dalam rangka 
memberikan perlindungan bagi kepentingan investor yang lemah secara lebih efektif.

\section{Analisis Pengaruh Tingkat Pendidikan Anggota Dewan Komisaris terhadap Kinerja Perusahaan}

Hipotesis $4\left(\mathrm{H}_{4}\right)$ penelitian ini adalah bahwa tingkat pendidikan anggota dewan komisaris berpengaruh positif terhadap kinerja perusahaan. Berdasarkan Tabel 4 dapat disimpulkan bahwa hasil temuan penelitian ini mendukung $\mathrm{H}_{4}$ untuk model ROE akan tetapi tidak mendukung $\mathrm{H}_{4}$ untuk model Tobin's Q. Untuk model ROE, nilai probabilitas $t$-statistic ( $p$-value) variabel tingkat Pendidikan komisaris (TPKOM) adalah 0,0294 $<(\alpha=5 \%)$ dengan tanda koefisien positif $(0,068)$ yang berarti bahwa variabel TPKOM berpengaruh signifikan positif terhadap kinerja perusahaan (dalam hal ini ROE).

Temuan penelitian ini sejalan dengan beberapa penelitian sebelumnyayang menunjukkan bahwa tingkat pendidikan anggota dewan komisaris mempunyai pengaruh signifikan terhadap kinerja, di antaranya adalah penelitian Ujunwa (2012), yang meneliti perusahaan terbuka di Nigerian Stock Exchange. Hasil temuannya adalah bahwa komposisi dewan komisaris yang anggotanya mempunyai Pendidikan $\mathrm{PhD}$ berpengaruh positif terhadap kinerja perusahaan. Alasannya adalah bahwa dengan tingkat pendidikan yang tinggi, maka dewan komisaris akan bertindak sesuai dengan kemampuan dan keterampilan yang dimilikinya untuk membantu fungsi tata kelola dalam pengambilan keputusan. Alasan ini juga dikemukakan oleh Carpenter dan Westphal (2001).

Sementara itu untuk model Tobin's Q, nilai probabilitas t-statistic ( $p$-value) variabel Tingkat pendidikan komisaris $(\mathrm{TPKOM})$ adalah $0,0039<(\alpha=5 \%)$, hanya saja variabel ini bertanda koefisien $-0,362$ yang berarti bahwa variabel TPKOM berpengaruh signifikan negatif terhadap kinerja perusahaan.

Temuan penelitian ini sejalan dengan beberapa penelitian sebelumnyayang menunjukkan bahwa tingkat pendidikan anggota dewan komisaris mempunyai pengaruh signifikan terhadap kinerja perusahaan, di antaranya adalah penelitian Phan (2016) yang melakukan penelitian terhadap perusahaan-perusahaan di Eropa dengan hasil bahwa dewan komisaris dengan tingkat pendidikan yang tinggi (gelar Master of Business Administration/MBA dan doktoral) tidak berpengaruh signifikan terhadap kinerja perusahaan. Alasannya adalah bahwa biasanya gelar pendidikan tersebut didapatkan jauh sebelum diangkat menjadi dewan komisaris sehingga pada saat menjadi komisaris pengetahuan yang didapatkan pada saat meraih gelar pendidikan sudah tidak sesuai lagi dengan kondisi saat ini. Hal yang sama juga ditunjukkan dalam penelitian Bathula (2008) dan Darmadi (2013).

\section{Analisis Pengaruh Usia Anggota Dewan Komisaris terhadap Kinerja Perusahaan}

Hipotesis $5\left(\mathrm{H}_{5}\right)$ penelitian ini adalah bahwa usia anggota dewan komisaris berpengaruh positif terhadap kinerja perusahaan. Berdasarkan Tabel 4 dapat disimpulkan bahwa hasil temuan penelitian ini mendukung $\mathrm{H}_{5}$ untuk model ROE dan model Tobin's Q. Untuk model ROE, nilai probabilitas $t$-statistic ( $p$-value) variabel usia anggota dewan komisaris (UKOM) adalah 0.0000 $<(\alpha=5 \%)$ dengan tanda koefisien positif $(0,002)$ yang berarti bahwa variabel UKOM berpengaruh signifikan positif terhadap kinerja perusahaan (dalam hal ini ROE). Demikian juga untuk model Tobin's $\mathrm{Q}$, nilai probabilitas $t$-statistic ( $p$-value) variabel usia nggota dewan komisaris (UKOM) adalah $0.0000<$ ( $\alpha=5 \%$ ) dengan tanda koefisien 0,039 yang berarti bahwa variabel UKOM berpengaruh signifikan positif terhadap kinerja perusahaan (dalam hal ini Tobin's Q).

Temuan penelitian ini sejalan dengan beberapa penelitian sebelumnya yang menunjukkan bahwa usia anggota dewan komisaris mempunyai pengaruh signifikan positif terhadap kinerja perusahaan, di antaranya adalah penelitianDagsson dan Larsson(2011). Alasan yang dikemukakan dalam temuan penelitian ini adalah bahwa dewan komisaris dengan usia yang matang dianggap mempunyai banyak pengalaman pasar dan juga pengalaman dengan berbagai pemangku kepentingan sehingga lebih efektif di dalam melakukan monitoring dan pengawasan atas jalannya perusahaan.

\section{Analisis Pengaruh Ukuran Perusahaan dan Usia Perusahaan terhadap Kinerja Perusahaan}

Berdasarkan Tabel 4 dapat disimpulkan bahwa untuk model ROE, nilai probabilitas t-statistic (p-value) variabel ukuran perusahaan (UKPER) adalah $0,0000<$ ( $\alpha=5 \%)$ dengan tanda koefisien positif $(0,044)$ yang berarti bahwa variabel UKPER berpengaruh signifikan positif terhadap kinerja perusahaan (dalam hal ini ROE). Temuan ini sejalan dengan hasil penelitian 
Wahyudin dan Solikhah (2017) terhadap perusahanperusahaan terbuka di Bursa Efek Indonesia. Hasil yang sama juga ditunjukkan dalam penelitian Mohamed et al. (2016). Perusahaan dengan ukuran yang besar seringkali memiliki beberapa keuntungan dibandingkan dengan perusahaan kecil, di antaranya adalah bahwa perusahaan besar memiliki peluang yang lebih baik dalam menciptakan dan menghasilkan dana secara internal dan mengakses sumber daya eksternal. Selain itu, perusahaan yang lebih besar mungkin mendapatkan keuntungan dari skala ekonomi dengan menciptakan hambatan masuk sehingga menimbulkan efek positif pada kinerja perusahaan (Marashdeh, 2014).

Sementara itu, untuk model Tobin's Q, nilai probabilitas $t$-statistic ( $p$-value) variabel ukuran perusahaan (UKPER) adalah $0,0000<(\alpha=5 \%)$ dengan tanda koefisien $-0,702$ yang berarti bahwa variabel UKPER berpengaruh signifikan negatif terhadap kinerja perusahaan (dalam hal ini Tobin's Q). Hal ini sejalan dengan temuan penelitian Ntim dan Osei (2011). Salah satu kemungkinannya adalah bahwa investor di pasar berpandangan bahwa perusahaan yang besar justru cenderung tidak seefisien perusahaan yang lebih kecil, karena dengan semakin bertambahnya ukuran perusahaan maka kendali oleh manajemen atas kegiatan strategis dan operasional makin berkurang. Hal ini yang mungkin ditanggapi dengan negatif oleh pasar.

Lebih lanjut, hasil penelitian ini menunjukkan bahwa nilai probabilitas t-statistic ( $\mathrm{p}$-value) variabel usia perusahaan (USPER) adalah $0.0000<(\alpha=5 \%)$ dengan tanda koefisien $-0,021$ yang berarti bahwa variabel USPER berpengaruh signifikan negatif terhadap kinerja perusahaan (dalam hal ini ROE). Kemungkinan yang menyebabkan usia perusahaan berpengaruh negatif terhadap kinerja adalah dengan semakin bertambahnya usia perusahaan maka perusahaan tersebut menjadi kurang dinamis dan kurang fleksibel dalam menyesuaikan dengan perubahan atau beradaptasi di lingkungan bisnis. Perusahaan yang usianya semakin tua dinilai tidak mampu menanggapi dengan cepat setiap perubahan lingkungan bisnis. (Marashdeh 2014).

Temuan penelitian ini sejalan dengan beberapa penelitian sebelumnya yang menunjukkan bahwa usia perusahaan mempunyai pengaruh signifikan negative terhadap ROE. Di antaranya adalah penelitian Kao et al. (2018)

\section{Implikasi Manajerial}

Dari hasil penelitian yang telah diuraikan di atas, terdapat beberapa implikasi manajerial yang dapat ditindaklanjuti. Di antaranya adalah bahwa Kuasa pemegang saham BUMN persero terbuka dalam hal ini Kementerian BUMN perlu menyusun kriteria tingkat kebutuhan dalam menentukan jumlah susunan anggota dewan komisaris di BUMN secara umum (tidak terbatas hanya pada BUMN persero terbuka).Selanjutnya, Kementerian BUMN agar membuat panduan dan arahan yang dapat digunakan oleh dewan komisaris dalam menentukan berapa jumlah rapat dewan komisaris yang paling optimal diselenggarakan dalam setahun. Misalnya panduan tersebut menyebutkan bahwa jumlah rapat dewan komisaris dilaksanakan berdasarkan ketentuan yang berlaku dan memperhatikan skala prioritas dan urgensinya.

Selain itu, Kementerian BUMN perlu menambahkan dalam peraturan yang sudah ada mengenai persyaratan dan kriteria profesionalisme dalam pengangkatan komisaris independen di BUMN. Kemudian bagi BUMN agar merevisi board manual khususnya terkait dengan peningkatan kompetensi dewan komisaris dengan menambahkan klausul wajibnya Pendidikan dan pelatihan dalam rangka peningkatan kapasitas dewan komisaris.

Implikasi manajerial berikutnya adalah bahwa Kementerian BUMN perlu mengatur secara lebih rinci mengenai persyaratan tingkat pendidikan minimal yang disyaratkan di dalam aturan pengangkatan calon anggota dewan komisaris. Selanjutnya Kementerian BUMN perlu melakukan seleksi terhadap calon anggota dewan komisaris yang diusulkan dengan mempertimbangkan keberagaman usia calon anggota dewan komisaris.

\section{KESIMPULAN DAN SARAN}

\section{Kesimpulan}

Hasil temuan penelitian ini tidak mendukung $\mathrm{H}_{1}$ (jumlah anggota dewan komisaris berpengaruh negatif terhadap kinerja perusahaan) untuk kedua model penelitian (model ROE dan model Tobin's Q). Untuk model ROE, variabel jumlah anggota dewan komisaris (JKOM) tidak mempunyai pengaruh yang signifikan terhadap kinerja perusahaan (dalam hal ini ROE). Sementara untuk model Tobin's Q, variabel 
JKOM berpengaruh signifikan positif terhadap kinerja perusahan (dalam hal ini Tobin's Q). Alasan yang paling mendukung temuan ini adalah bahwa dengan semakin bertambahnya jumlah anggota dewan komisaris yang sebagian besar berafiliasi dengan pihak pemerintah maka hal ini membawa keuntungan bagi BUMN persero terbuka tersebut dalam memperoleh dukungan insentif dari pemerintah. Bagi investor, keadaan seperti ini dianggap akan meningkatkan value BUMN persero terbuka tersebut.

Selanjutnya, hasil penelitian ini mendukung $\mathrm{H}_{2}$ (rapat dewan komisaris berpengaruh positif terhadap kinerja perusahaan) untuk model ROE akan tetapi tidak mendukung H2 untuk model Tobin's Q. Untuk model ROE, variabel rapat dewan komisaris (RKOM) berpengaruh signifikan positif terhadap kinerja perusahaan (dalam hal ini ROE). Alasan yang mendukung temuan ini adalah bahwa dengan semakin seringnya rapat yang dilakukan, maka dewan komisaris akan semakin sering menyampaikan informasi strategis dan masukan/nasihat kepada direksi. Selain itu rapat dewan komisaris akan membahas hal-hal yang terkait dengan pengendalian internal dan juga manajemen risiko perusahaan secara lebih mendalam sehingga meningkatkan kewaspadaan bagi direksi dalam pengambilan keputusan strategis. Sedangkan pada model Tobin's Q, variabel RKOM tidak mempunyai pengaruh yang signifikan terhadap kinerja perusahan (dalam hal ini Tobin's Q). Alasannya adalah semakin banyak frekuensi rapat dewan komisaris yang dilakukan menandakan perusahaan tersebut dalam keadaan yang tidak baik. Pasar akan bereaksi negatif terhadap hal yang demikian. Sementara itu, dengan semakin banyaknya jumlah frekuensi rapat dewan komisaris maka akan meningkatkan biaya yang akan berdampak negatif terhadap nilai perusahaan.

Kemudian, hasil temuan penelitian ini mendukung $\mathrm{H}_{3}$ (jumlah anggota dewan komisaris independen berpengaruh positif terhadap kinerja perusahaan) untuk kedua model penelitian (model ROE dan model Tobin's Q). Variabel jumlah anggota dewan komisaris independen (KINDP) berpengaruh signifikan positif terhadap kinerja perusahaan. Alasan yang mendukung temuan ini adalah bahwa dengan semakin banyakjumlah komisaris independen dalam susunan dewan komisaris maka proses monitoring yang dijalankan akan lebih efektif, selain itu keberadaan komisaris independen memberikan keseimbangan antara pemilik saham mayoritas dan minoritas, karena komisaris independen dianggap memberikan perlindungan kepada pemilik saham minoritas.

Hasil penelitian selanjutnya adalah terkait dengan pengaruh tingkat pendidikan anggota dewan komisaris terhadap kinerja perusahaan. Hasilnya mendukung $\mathrm{H}_{4}$, yaitu variabel tingkat pendidikan dewan komisaris (TPKOM) berpengaruh signifikan positif terhadap kinerja perusahaan (dalam hal ini ROE). Alasannya adalah bahwa dengan tingkat pendidikan yang tinggi, maka dewan komisaris akan bertindak sesuai dengan kemampuan dan keterampilan yang dimilikinya untuk membantu fungsi tata kelola dalam pengambilan keputusan. Hal ini sejalan dengan teori upper echelon yang diungkapkan oleh Hambrick dan Mason (1984), bahwa pendidikan formal merupakan salah satu variabel penting sumber daya manusia, dasar pengetahuan dan kompetensi intelektual. Oleh karena itu salah satu faktor penting yang harus dimiliki oleh dewan komisaris dalam monitoring dan pemberian nasihat adalah ilmu pengetahuan yang diperolehnya pada saat menempuh pendidikan formal. Sementara untuk model Tobin's Q, meskipun variabel TPKOM berpengaruh signifikan, tetapi arah pengaruhnya adalah negatif terhadap kinerja perusahaan (dalam hal ini Tobin's Q) dengan demikian temuan ini tidak mendukung $\mathrm{H}_{4}$ penelitian. Alasan yang mendukung temuan ini adalah bahwa investor di pasar tidak hanya sebatas melihat tingkat pendidikan formal yang dimiliki oleh dewan komisaris, akan tetapi melihat pengalaman kerja sebelumnya, kemampuan manajerialnya dan jaringan yang dimilikinya. Di dalam temuan ini juga menunjukkan bahwa tingkat pendidikan formalyang dimiliki oleh dewan komisaris tetap menjadi aspek yang sangat penting dalam pelaksanaan tugas pengawasan dan monitoring jalannya perusahaan.

Temuan penelitian selanjutnya tentang pengaruh usia anggota dewan komisaris terhadap kinerja perusahaan menunjukkan bahwa variabel usia anggota dewan komisaris (UKOM) berpengaruh signifikan positif terhadap kinerja perusahaan (ROE dan Tobin's Q). Dengan demikian, penelitian ini berhasil membuktikan $\mathrm{H}_{5}$. Alasan yang mendukung temuan ini adalah bahwa tingkat kematangan usia anggota dewan komisaris ditandai dengan karakteristik semakin banyak pengalaman dalam menghadapi berbagai macam permasalahan dan juga kehati-hatiannya dalam mengambil risiko. Bagi BUMN persero terbuka yang merupakan perusahaan negara yang tunduk pada rezim 
hukum keuangan negara, keberadaan dewan komisaris yang berusia matang dianggap lebih memberikan keuntungan bagi peningkatan kinerja perusahaan.

\section{Saran}

Terdapat beberapa saran bagi peneliti yang akan melakukan penelitian selanjutnya dengan topik yang sama. Pertama, disarankan untuk melakukan penelitian dengan cara membandingkan antara BUMN persero terbuka dengan perusahaan terbuka lainnya yang berada pada sektor industri yang sama. Alternatif yang lain adalah objek penelitiannya masih menggunakan BUMN persero terbuka tetapi yang sektor industrinya sejenis misalnya meneliti BUMN persero terbuka yang bergerak di bidang perbankan. Alternatif lainnya adalah menggunakan objek penelitian BUMN (bukan hanya BUMN persero terbuka) dalam sektor industri yang sejenis, Dengan objek penelitian perusahaan yang industrinya sejenis maka penggunaan variabel ROE sebagai variabel dependen akan lebih sesuai. Kedua, disarankan bagi penelitian selanjutnya agar menggunakan variabel nilai pasar yang lain seperti Earning Per Share (EPS). Formula EPS adalah membagi laba bersih setelah dikurangi dengan saham preferen dengan jumlah saham yang beredar pada akhir tahun. Untuk objek penelitian BUMN persero terbuka, jumlah lembar saham yang beredar pada umumnya tidak berubah sehingga alternatif penggunaan variabel EPS dalam penelitian akan lebih tepat digunakan.

\section{DAFTAR PUSTAKA}

Afshan, Sherwani FAK, Kabbir G, Khan MN, Islam F. 2016. Impact of corporate governance on firm financial performance: an empirical evidence from textile sector of Pakistan. International Journal of Scientific and Research Publications 6 (9) : 449-454.

Ahmed E, Hamdan A. 2015. The impact of corporate governance on firm performance: evidence from Bahrain stock exchange. European Journal of Business and Innovation Research 3(5) : 25-48.

Al-Daoud KI, Saidin SZ, Abidin S. 2016. Board meeting and firm performance: evidence from the Amman stock exchange. Corporate Board: Role, Duties \& Composition 12 (2): 6-11.

Astuti FY, Wahyudi S, Mawardi W. 2018. Analysis of effect of firm size, institutional ownership, profitability, and leverage on firm value with corporate social responsibility (csr) disclosure as intervening variables (study on banking companies listed on bei period 2012-2016). Jurnal Bisnis STRATEGI 27(2): 95 - 109. doi:10.14710/jbs.27.2.95-109.

Bathula H. 2008. Board characteristics and firm performance: evidence from New Zealand [tesis].New Zealand (NZ). AUT University.

Bhat KU, Chen Y, Jebran K, Bhutto NA. 2018. Corporate governanceand firm value: a comparative analysis of state and non-state owned companies in the context of Pakistan. Corporate Governance: The International Journal of Business in Society 18 (6): 1196-1206.

Black B, Khanna V. 2007. Can corporate governance reforms increase firm market values? Event study evidence from India. Journal of Empirical Legal Studies 4(4): 749-796.

Black B, Kim W. 2012. The effect of board structure on firm value: A multiple identification strategies approach using Korean data. Journal of Financial Economics 104: 203-226.

Bohorquez MVU, Ferrero JM, Sánchez IMG. 2018. Board independence and firm performance: The moderating effect of institutional context. Journal of Business Research 88: 28-43.

Buachoom W. 2018. How Do Board Structures of Thai Firms Influence on Different Quantile Levels of Firm Performance? Advances in Pacific Basin Business, Economics and Finance (Advances in Pacific Basin Business, Economics and Finance 6: 157-189.

Carpenter MA, Westphal JD. 2001. The Strategic Context of External Network ties: Examining the impact of director appointments on board involvement in strategic decision making. Academy of Management 44(4): 639-660.

Chou HI, Chung H, Yin X. 2013. Attendance of board meetings and company performance: evidence from Taiwan. Journal of Banking \& Finance 37: 4157-4171.

Coles JL, Daniel N, Naveen, L.2008. Boards: Does one size fit all. Journal of Financial Economics 87(2): 329-356.

Dagsson S, Larsson E. 2011. How age diversity on the board of directors affects firm performance [tesis]. Blekinge. Blekinge Institute of Technology School of Management.

Darmadi S. 2013. Board members' education and firm performance: evidence from a developing economy. International Journal of Commerce 
and Management 23(2):113-135.

Darweesh M. 2015. Correlations between corporate governance, financial performance, and market value [disertasi]. Minnesota: Walden University.

Gîrbină MM, Albu CN, Albu N. 2012. Board members' financial education and firms' performance: empirical evidence for Bucharest stock exchange companies. International Journal of Economics and Management Engineering 6(9): 2343-2347.

Hidayat AA, Utama S. 2016. Board characteristics and firm performance: evidence from Indonesia. International Research Journal of Business Studies 8 (3): 137-154.

Kao MF, Hodgkinson L, Jaafar A. 2018. Ownership structure, board of directors and firm performance: evidence from Taiwan. The International Journal of Business in Society 19 (1) : 189-216.

Liu Y, Miletkov MK, Wei Z, Yan T. 2015. Board independence and firm performance in China. Journal of Corporate Finance 30:223-244.

Marashdeh Z.M.S. 2014. The effect of corporate governance on firm performance in Jordan [tesis]. Lanchasire: University of Central Lanchasire.

Meyer E, Wet J. 2013. The impact of board structure on the financial performance of listed South African companies. Corporate Board: Role, Duties \& Composition 9 (3) :19-31.

Mohamed HMA, Zhou X, Amin M. 2016. The impact of corporate governance on Chinese firms performance: a board structure perspective. International Journal of Managerial Studies and Research 4(6) : 1-8.

Nakano M, Nguyen P. 2011. Do older boards affect firm performance? An empirical analysis based on Japanese firms. https://ssrn.com/ abstract=1879250. [30 Mar 2019].

Ntim CG, Osei KA. 2011. The impact of corporate board meetings on corporate performance in
South Africa. African Review of Economics and Finance 2(2): 83-103.

Phan H. 2016. Board of Director Education and Firm Performance: A Dynamic Approach [Tesis]. Aalto: Department of Finance Aalto University School of Business

Rashid A. 2018. Board independence and firm performance: evidence from Bangladesh. Future Business Journal 4: 34-49.

Rodriguez-Fernandez M, Fernandez-Alonso S, Rodriguez-Rodriguez J. 2014. Board characteristics and firm performance in Spain. Corporate Governance 14 (4): 485-503.

Selcuk EA. 2016. Does firm age affect profitability? Evidence from Turkey. International Journal Of Economic Sciences 5(3): 1-9 doi:10.20472/ ws.2016.5.3.001.

Ujunwa A. 2012. Board characteristics and the financial performance of Nigerian quoted firms. Corporate Governance: The international journal of business in society 12(5): 656-674.

Vafeas N. 1999. Board meeting frequency and firm performance. Journal of Financial Economics 53(1): $\quad$ 113-142. Doi:10.1016/S0304405X(99)00018-5.

Vivekananda A, Achsani NA, Maulana TNA. 2019. Pengaruh variabel kinerja keuangan perusahaan dan makroekonomi terhadap harga saham batubara: perbandingan antara emiten LQ45 dan nonLQ45. Jurnal Aplikasi Manajemen dan Bisnis 5(3): 347-360

Wahyudin A, Solikhah B. 2017. Corporate governance implementation rating in Indonesia and its effects on financial performance. Corporate Governance: The International Journal of Business in Society 17 (2): 250-265. 